Article

\title{
The Dominance Hierarchy of Wood-Eating Termites from China
}

\author{
Theodore A. Evans ${ }^{1, *}$ and Boris Dodji Kasseney ${ }^{2}$ \\ 1 School of Biological Sciences, University of Western Australia, Perth WA 6009, Australia \\ 2 Laboratory of Applied Entomology, Faculty of Sciences, University of Lomé, BP 1515 Lomé 01, Togo \\ * Correspondence: theo.evans@uwa.edu.au; Tel.: +61-8-6488-8672
}

Received: 25 June 2019; Accepted: 12 July 2019; Published: 18 July 2019

\begin{abstract}
Competition is a fundamental process in ecology and helps to determine dominance hierarchies. Competition and dominance hierarchies have been little investigated in wood-eating termites, despite the necessary traits of similar resources, and showing spatial and temporal overlap. Competition and dominance between five species of wood-eating termites found in Huangzhou, China, was investigated in three laboratory experiments of aggression and detection, plus a year-long field survey of termite foraging activity. Dominance depended on body size, with largest species winning overwhelmingly in paired contests with equal numbers of individuals, although the advantage was reduced in paired competitions with equal biomass. The termites could detect different species from used filter papers, as larger species searched through paper used by smaller species, and smaller species avoided papers used by larger species. The largest species maintained activity all year, but in low abundance, whereas the second largest species increased activity in summer, and the smallest species increased their activity in winter. The termite species displayed a dominance hierarchy based on fighting ability, with a temporal change in foraging to avoid larger, more dominant species. The low abundance of the largest species, here Macrotermes barneyi, may be a function of human disturbance, which allows subordinate species to increase. Thus, competitive release may explain the increase in abundance of pest species, such as Coptotermes formosanus, in highly modified areas, such as urban systems.
\end{abstract}

Keywords: Macrotermes; Odontotermes; Coptotermes; Reticulitermes; aggression tests; competitive release; urban ecosystems

\section{Introduction}

A fundamental process in ecology is competition for resources between organisms with similar requirements [1-3]. Competition may be direct or indirect, for food, shelter, and other resources. Direct competition for food leads to dominance hierarchies, with the species able to use superior strength to dominate the most preferred food resource (e.g., for the classic experiments using granivorous insects in stored products, see [4-7]). The subordinate species may then specialise on less preferred food or access food in different locations or at different times than the dominant species [8-11].

Wood-eating termites offer an excellent system to consider competition and dominance hierarchies because the conditions for competition are present. Many species are found in the same habitat, or even in the same piece of wood [12], from the tropics to the warm temperate latitudes (ca. 35 $)$ [13]. These termites utilise the cellulose in wood as food [14,15]. Studies on natural durability of wood against termites highlight wood species with high resistance, but they also show that termites do consume a wide range of wood species [16-18]. 
Although there are few studies that have considered whether competition and dominance hierarchies have evolved in termite communities, many studies have noted or used aggression in termites. These studies have mostly focussed on identifying colonies using aggression tests, beginning with [19], reviewed in [20,21], and/or identifying chemicals used to identify colonies [22-25]. Other studies have inferred competition between termite colonies due to the overdispersed spatial patterns of mound-nests [26-28]. Such studies strongly suggest that competition is occurring, but they do not attempt to measure its effects between species or infer competitive hierarchies.

The aim of this study was to test for competition between five species of sympatric wood-eating termites in China, to identify a dominance hierarchy, and infer factors influencing pest status. The location in China had a moderately diverse generic diversity [13,29], including several species of fungus-growing Macrotermitinae, which appear to be the dominant wood-feeders when present, and some species of Coptotermes and Reticulitermes in the Rhinotermitidae, which often become pests in disturbed habitats [30-32]. The study system is therefore diverse enough to consider general patterns that may be relevant elsewhere in Asia and Africa, where fungus-growing termites are present, but not so diverse for the logistics of the experiment to be overwhelming.

\section{Materials and Methods}

Termites were collected from the Hangszhou Botanic Gardens west of the West Lake, in the city of Hangzhou, Zheijiang province, China. The Botanic Gardens are contiguous with other gardens adjacent to the West Lake to the east, and with forest to the west, with a total wooded or forested areas of ca. 15 square kilometres. The termites were collected from dead wood lying on the ground or from wood-filled bait stations between October and November 2009.

The species were collected and identified [29] as (in decreasing body sizes): Macrotermes barneyi Light, Odontotermes formosanus (Shiraki), Coptotermes formosanus Shiraki, Odontotermes hainanensis Light, and Reticulitermes flaviceps (Oshima). Ten individuals from each caste of each colony of each species were weighed to determine average sizes (Table 1). Termites were separated from the wood in the laboratory and placed in 'holding containers', which were glass Petri dishes (diameter $200 \mathrm{~mm}$ ) filled with rolled filter paper (rolls were $45 \mathrm{~mm}$ long $\times 6 \mathrm{~mm}$ diameter of Whattman No. 1 filter paper). The rolled filter paper gave the termites retreats in which to rest and receive food and moisture. The rolls were used in Experiment 3 (see below).

Table 1. The weights (mean \pm standard error) of the different castes for each termite species. Note M. barneyi has two castes of workers (large and small). Only workers were used in the laboratory experiments; soldier weights are provided for comparison only. Numbers of individuals for equal biomass (mean \pm standard error) were based on the average weight of $5 \mathrm{M}$. barneyi workers ( 3 large + 2 small) of $42.1 \mathrm{mg}$.

\begin{tabular}{ccccc}
\hline Species & \multicolumn{2}{c}{ Worker } & Soldier & $\begin{array}{c}\text { Number of Individuals for } \\
\text { Equal Biomass }\end{array}$ \\
\hline Macrotermes barneyi & large & $10.41 \pm 0.54$ & $22.43 \pm 0.52$ & 3 \\
Odontotermes formosanus & small & $5.45 \pm 0.32$ & $12.01 \pm 1.67$ & 2 \\
Coptotermes formosanus & & $4.99 \pm 0.19$ & $4.57 \pm 0.13$ & $8.8 \pm 0.9$ \\
Odontotermes hainanensis & & $4.05 \pm 0.06$ & $4.43 \pm 0.06$ & $10.9 \pm 1.3$ \\
Reticulitermes flaviceps & & $2.13 \pm 0.06$ & $2.11 \pm 0.05$ & $23.0 \pm 1.0$ \\
\hline
\end{tabular}

\subsection{General Experimental Method}

General setup for all experiments was as follows. Glass Petri dishes (diameter $90 \mathrm{~mm}$ ) lined with moist filter paper were used for all experiments. Only workers were used in experiments, because soldiers were rare (sometimes less than one percent of individuals) and insufficient for appropriate replication. Similar petri dish experiments have been used in many studies [23,33-36], which have 
found that worker termites are usually aggressive against other termite species (for reviews see [21,37]). No individual was used twice. Termites used in the experiments were conducted between four hours and five days of collection, as aggression decreases with time in the laboratory [33,38].

\subsection{Experiment 1: Equal Number of Termites}

Five healthy (intact, walking normally) workers were chosen and placed into vertically placed Perspex tubes $(\emptyset 15 \mathrm{~mm})$ in the Petri dishes. The Perspex tubes were used to contain the termites and allow time for them to recover from relocation. In the experimental treatments, five workers of each of the two tested species were placed in two separate Perspex tubes. In the controls, five workers from the same colony were placed in two Perspex tubes. About five minutes after placement, when the termites had either slowed or stopped walking, the Perspex tubes were removed and the Petri dishes were covered. Petri dishes were observed for ca. 10 minutes and then placed in a constant temperature $\left(25^{\circ} \mathrm{C}\right)$ chamber for ca. 24 hours (22-26 hours), after which the numbers of live and dead termites were counted. Dead termites were separated into mutilated (presumed killed during fighting) and intact (presumed to have died for other reasons). Note that statistical analyses were performed on number of live termites only. There were five replicates for controls for all species, and 10 replicate dishes for each species combination, except for those with $O$. hainanensis, which had five replicates (due to low numbers of termites collected).

\subsection{Experiment 2: Equal Biomass of Termites}

Macrotermes barneyi was chosen as the reference species for the equal biomass experiment, because it was the largest species. The reference biomass $(42.1 \mathrm{mg}$ ) was based on five healthy (intact, walking normally) M. barneyi workers-three large workers plus two small workers, which was approximately the ratio found in field collections. The equivalent biomass of the other species comprised 8-10 workers of O. formosanus, 10-12 workers of C. formosanus, 22-24 workers of O. hainanensis, and 19-23 workers of $R$. flaviceps (Table 1). Note the variation in number of workers per replicate was due to variation in weight of individual termites, as the termites for each replicate were counted and weighed until they reached the reference biomass. The same protocol and same number of replicates were followed as for experiment 1 .

\subsection{Experiment 3: Chemical Detection of Species}

This experiment tested whether termites could detect other species indirectly (chemically), from their habitations. The rolled filter papers ( $45 \mathrm{~mm}$ long $\times 6 \mathrm{~mm}$ diameter) from the 'holding container' Petri dishes were used. The termites had lived in the rolled filter papers (hence 'rolls') for up to seven days, and rolls with signs of inhabitation (chewing, building, and faecal staining) were chosen. Three rolls were placed on the inside edge in each experimental Petri dish at $120^{\circ}$ to each other (forming a triangle): one roll from the same species (but different colony), one roll from another species, and one blank (unused) roll. Ten workers were chosen and placed into a Perspex tube in the centre of each Petri dish. About five minutes after placement, when the termites had stopped walking, the Perspex tubes were removed and the Petri dishes were covered. Petri dishes were placed in a CT chamber for 2 hours, then examined, then for a further 22 hours, after which the number and location of alive and dead termites were recorded in the same species roll, different species roll, blank roll, or not inside a roll. Odontotermes hainanensis was not used in this experiment, as there were too few individuals remaining from previous experiments.

\subsection{Field Survey}

Species competing for the same resources may reduce competitive interactions spatially or temporally. To test this possibility, the dead wood on the ground in the Botanic Gardens was surveyed over one year for patterns of the termite species collected for the laboratory experiments. There were limitations, due to the management of the gardens, so attack on trees and some areas could not be 
surveyed. Therefore, a haphazard survey was designed. Four areas were designated, and transects were placed. The transects were walked, and the first 200 pieces of dead wood on the ground were examined for termite activity. The species identity was recorded when live termites were found.

\subsection{Analysis}

In all experiments, the numbers of live termites were converted to proportion survival in order to avoid issues with the different numbers of termites for each species used in experiment 2 . For Experiments 1 and 2, the proportion survival for each species was compared against each pair combination using one-way ANOVA tests, with Bonferroni corrected post-hoc tests. For Experiment 3 , the proportion of termites in or on the rolls of the same species, other species, or blank rolls were compared across species, after 2 and 24 hours, in a repeated measures ANOVA, and then within each species with an ANOVA after 2 hours. For the field survey, the number of pieces of dead wood with each termite species was compared over the 12 months of the year, and the proportion of dead wood occupied by termites was compared for each species by one-way ANOVA and MANOVA tests, with Bonferroni corrected post-hoc comparisons.

\section{Results}

\subsection{Experiment 1: Equal Number of Termites}

Termites in control treatments usually walked quickly around the petri dishes for five minutes or so, then slowed or stopped walking. During this time, they encountered other termites, usually stopping to antennate or without obvious change in behaviour. After one day, these termites had high survival (80-100\%) and had usually chewed some of the filter paper in the petri dishes. Termites in mixed species treatments usually walked quickly around the petri dishes when first released, but when they encountered other heterospecific termites, they reacted either by lunging and biting (larger species) or retreating (smaller species). After 10 minutes, most individuals were either still walking rapidly or engaged in fighting. After one day, these termites had moderate (40-60\%) to low (0-10\%) survival, and there were no signs of chewed filter paper in the petri dishes.

Macrotermes barneyi had a uniformly high level of survival regardless of co-placed species. Proportion survival averaged $0.80 \pm 0.07$ and did not differ across treatments $\left(F_{4,40}=1.770, p=0.154\right.$; Figure 1A).

All other termite species had variable survival, which depended on co-placed species. Proportion survival of $O$. formosanus was significantly higher in controls and $R$. flaviceps, moderate to high with $O$. hainanensis, low with $C$. formosanus, and zero with $M$. barneyi $\left(F_{4,33}=33.178, p<0.001\right.$; Figure $\left.2 \mathrm{~A}\right)$.

For C. formosanus, proportion survival was significantly higher in controls, with $O$. hainanensis and $R$. flaviceps, but significantly lower with $M$. barneyi and $O$. formosanus $\left(F_{4,35}=51.505, p<0.001\right.$; Figure 3A).

Proportion survival of $O$. hainanensis was significantly higher in controls, medium with $R$. flaviceps, and significantly lower with the three other species $\left(F_{4,18}=16.207, p<0.001\right.$; Figure $\left.4 \mathrm{~A}\right)$. For Reticulitermes flaviceps, the proportional survival was significantly higher in controls, with no difference with the four other species $\left(F_{4,35}=43.913, p<0.001\right.$; Figure $\left.5 \mathrm{~A}\right)$.

Macrotermes barneyi had a more variable pattern of survival with equal biomass than for equal numbers. Proportion survival was significantly higher in controls and with $R$. flaviceps, significantly lower with $O$. formosanus, and moderate with all other species $\left(F_{4,34}=10.273, p<0.001\right.$; Figure $\left.1 \mathrm{~B}\right)$. Proportion survival of $O$. formosanus was significantly higher in controls, moderate with $O$. hainanensis and $R$. flaviceps, and significantly lower with $M$. barneyi and $C$. formosanus $\left(F_{4,31}=32.442, p<0.001\right.$; Figure 2B). 
For Coptotermes formosanus, proportion survival was significantly higher in controls, moderate with $O$. hainanensis and $R$. flaviceps, and significantly lower with $M$. barneyi and $O$. formosanus $\left(F_{4,35}=30.126\right.$, $p<0.001$; Figure 3B). Proportion survival of $O$. hainanensis was significantly higher in controls, medium with $R$. flaviceps, and significantly lower with the three other species $\left(F_{4,15}=48.738, p<0.001\right.$; Figure $\left.4 \mathrm{~B}\right)$. For Reticulitermes flaviceps, the proportional survival was significantly higher in controls, with no difference with the four other species $\left(F_{4,35}=135.120, p<0.001\right.$; Figure $\left.5 \mathrm{~B}\right)$.

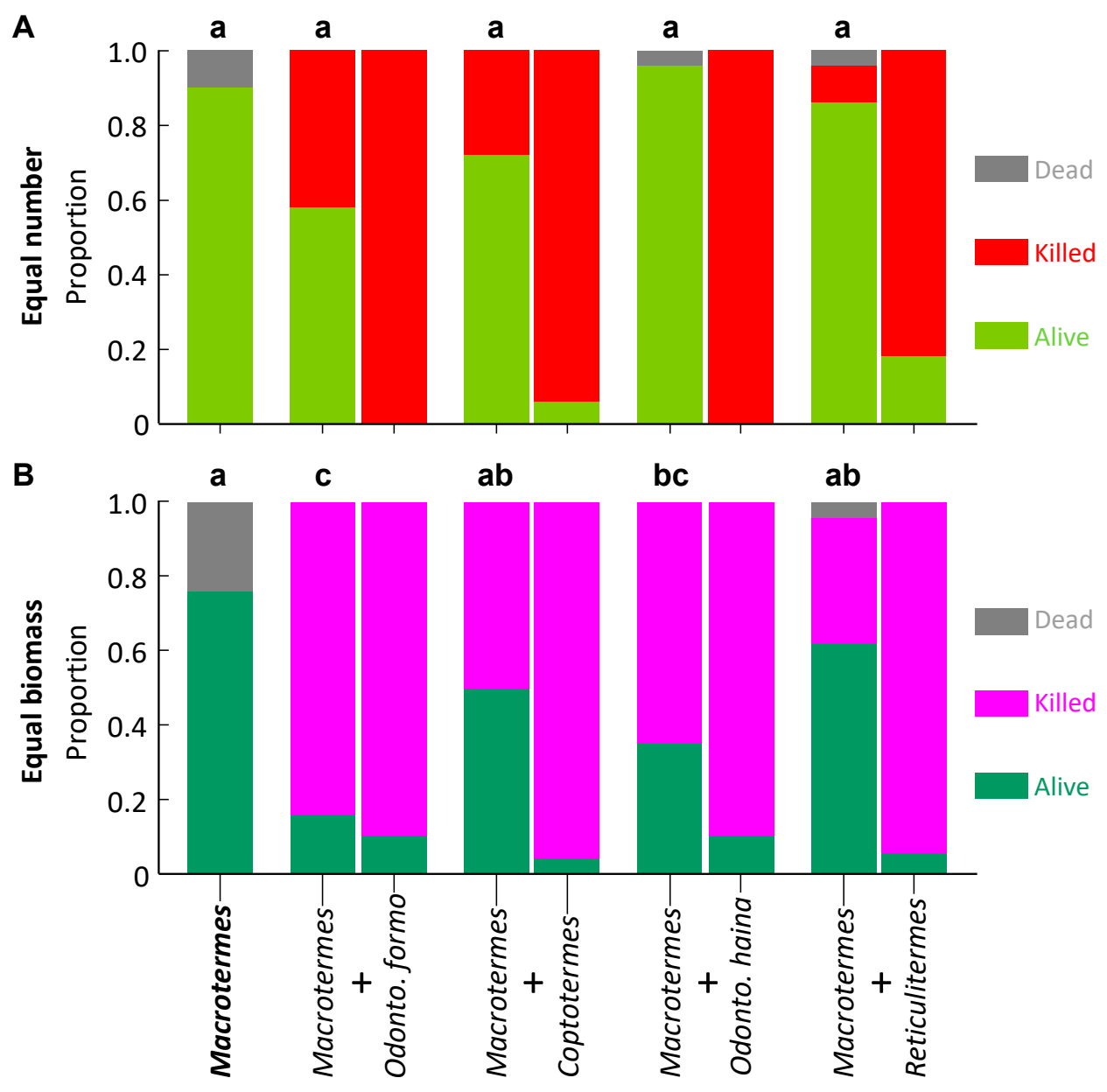

Figure 1. Survival of Macrotermes barneyi in laboratory aggression experiments. The control appears as a single column as it contains one species, whereas paired species treatments are paired columns, the $M$. barneyi on the left of each pair. Columns surmounted by different letters signify significantly different proportion survival (Bonferroni corrected pairwise comparisons) for M. barneyi. (A) Equal number of termites; (B) Equal biomass of termites. 

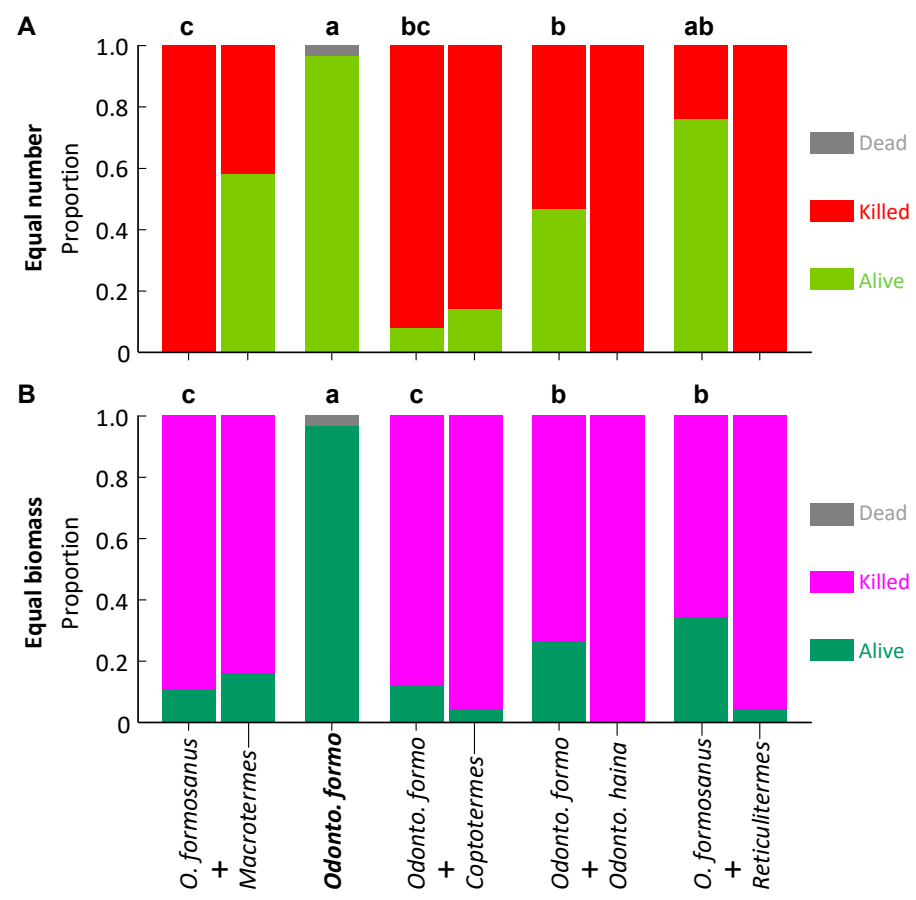

Figure 2. Survival of Odontotermes formosanus in laboratory aggression experiments. The control appears as a single column as it contains one species, whereas paired species treatments are paired columns, the O. formosanus on the left of each pair. Columns surmounted by different letters signify significantly different proportion survival (Bonferroni corrected pairwise comparisons) for O. formosanus. (A) Equal number of termites; (B) Equal biomass of termites.

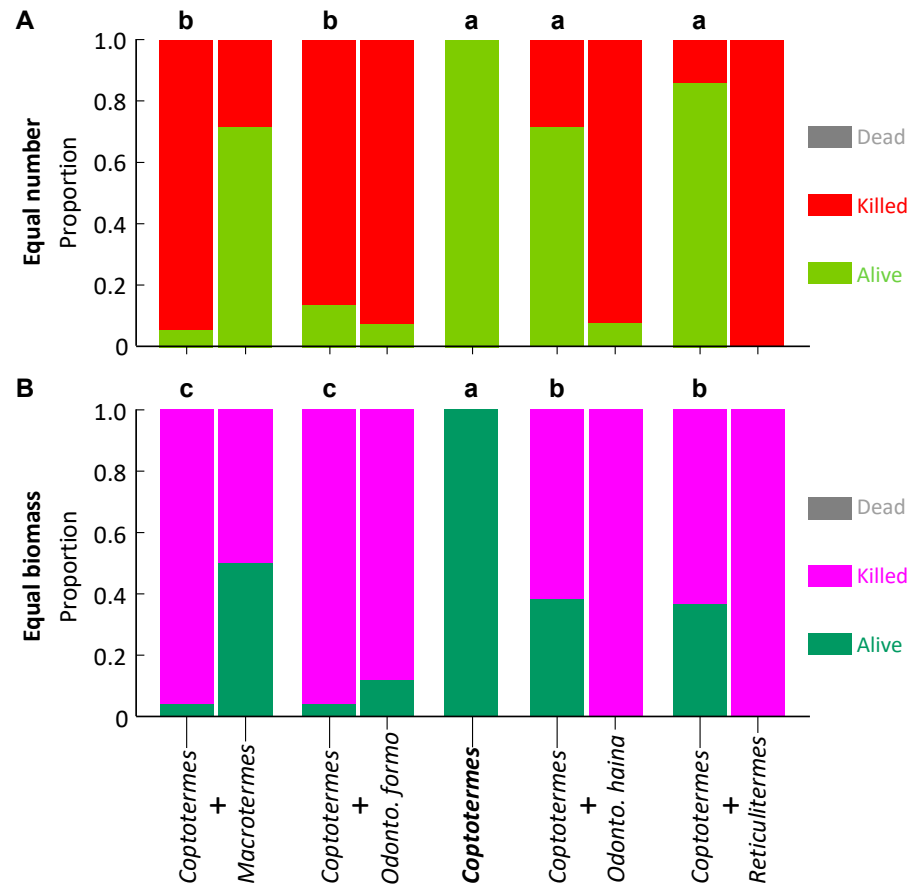

Figure 3. Survival of Coptotermes formosanus in laboratory aggression experiments. The control appears as a single column as it contains one species, whereas paired species treatments are paired columns, the C. formosanus on the left of each pair. Columns surmounted by different letters signify significantly different proportion survival (Bonferroni corrected pairwise comparisons) for C. formosanus. (A) Equal number of termites; (B) Equal biomass of termites. 


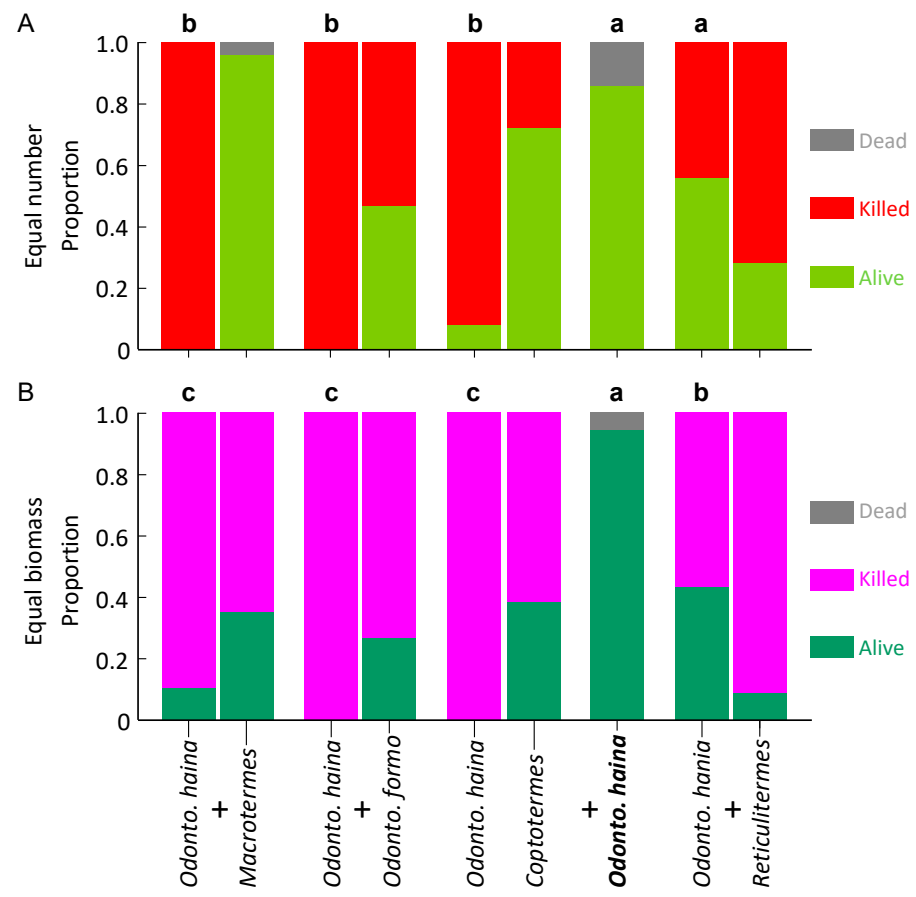

Figure 4. Survival of Odontotermes hainanensis in laboratory aggression experiments. The control appears as a single column as it contains one species, whereas paired species treatments are paired columns, the O. hainanensis on the left of each pair. Columns surmounted by different letters signify significantly different proportion survival (Bonferroni corrected pairwise comparisons) for O. hainanensis. (A) Equal number of termites; (B) Equal biomass of termites.

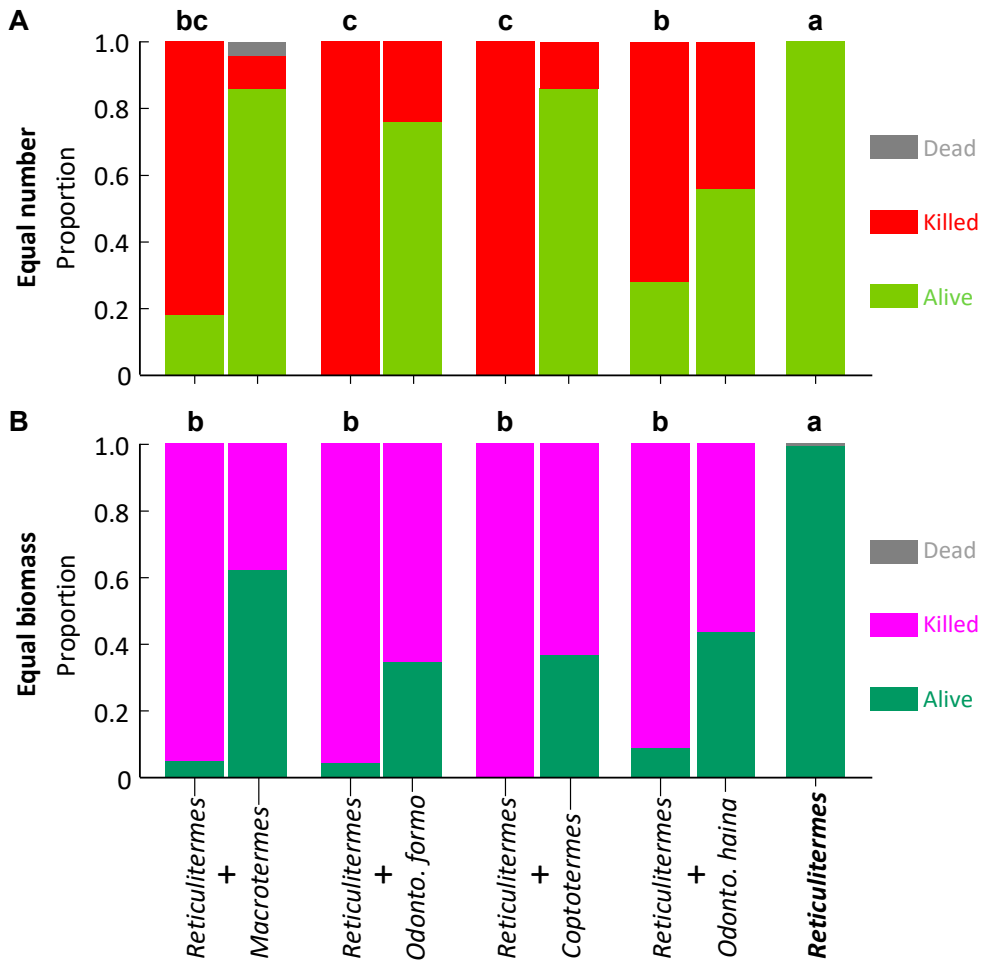

Figure 5. Survival of Reticulitermes flaviceps in laboratory aggression experiments. The control appears as a single column as it contains one species, whereas paired species treatments are paired columns, the $R$. flaviceps on the left of each pair. Columns surmounted by different letters signify significantly different proportion survival (Bonferroni corrected pairwise comparisons) for R. flaviceps. (A) Equal number of termites; (B) Equal biomass of termites. 


\subsection{Experiment 2: Equal Biomass of Termites}

The pattern of behaviours observed in 'equal biomass' were similar to those seen in 'equal numbers of termites' experiments: slow and calm movements in controls, fast and aggressive movements in mixed species. As the numbers of the smaller species of termite were higher, both the aggressive behaviour and mortality were higher.

\subsection{Experiment 3: Chemical Detection of Species}

After placement, termites walked around the petri dish, around, on, and through the rolled filter papers. The walking was variable; sometimes rapid, but rarely slow. After two hours, most of the termites had stopped walking and were motionless on one of the three filter papers, although some of the termites were still walking, albeit more slowly. After 24 hours, all termites had stopped walking and were inside rolled filter papers. The locations of termites varied from their own species and others, or blank papers, but did not change markedly over time (Figure 6).

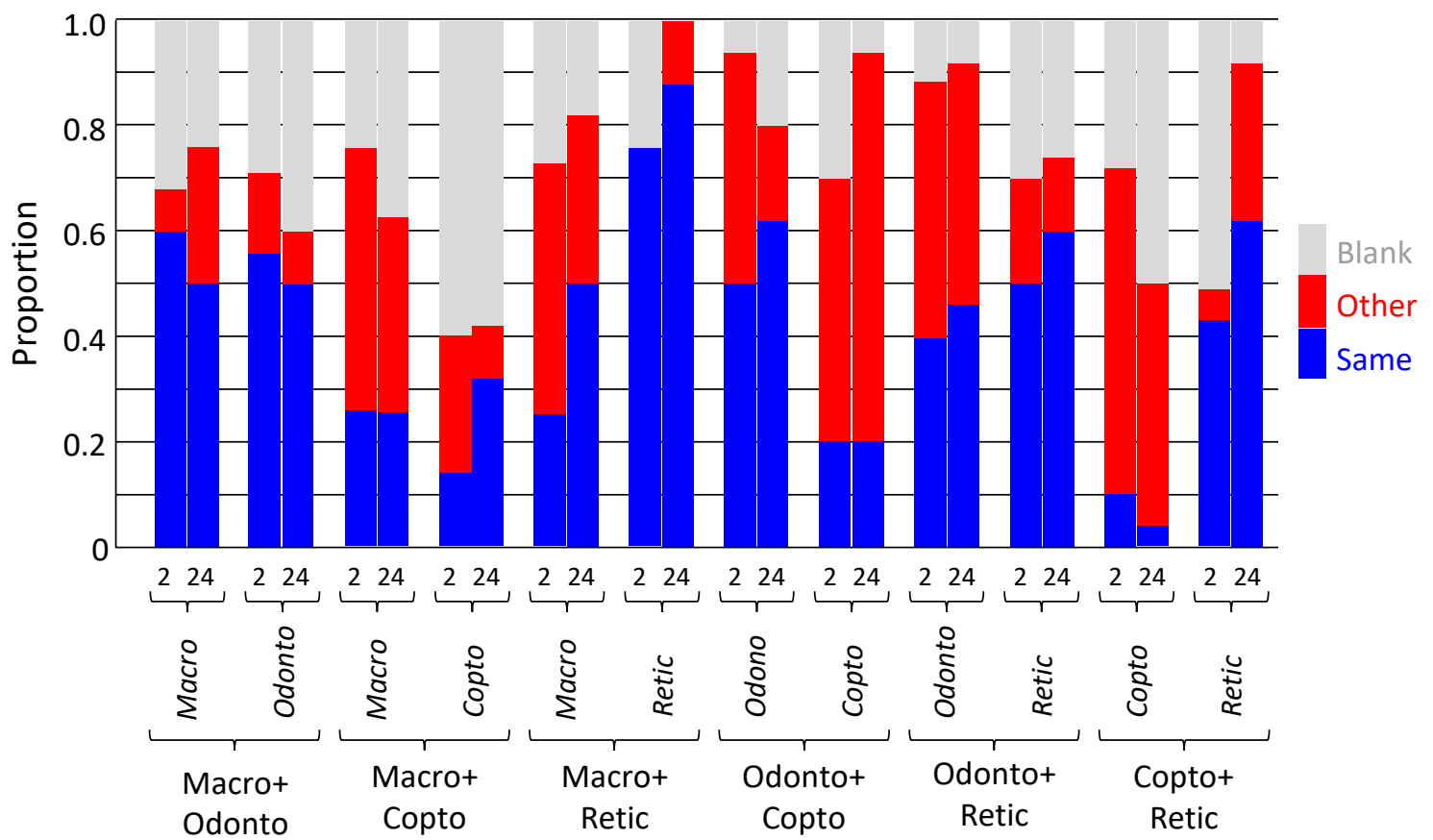

Figure 6. Location of termites in chemical detection experiment. Termites were offered three pieces of rolled filter paper: from the same species (another colony), other species, or blank. Locations recorded after 2 and 24 hours. Macro = Macrotermes barneyi; Odonto = Odontotermes formosanus; Copto $=$ Coptotermes formosanus $;$ Retic $=$ Reticulitermes flaviceps.

For M. barneyi, the majority (50-60\%) of individuals were on their own paper when paired with paper from $O$. formosanus, but were on the other species paper when paired with $C$. formosanus and R. flaviceps (both $40-50 \%$ ). Around $20-30 \%$ used blank paper. For C. formosanus, the majority of individuals $(60 \%)$ were on blank paper when paired with paper from M. barneyi, but were mostly on the other species paper when paired with O. formosanus (50-75\%) and R. flaviceps (50-60\%). For O. formosanus, the majority of individuals were on their own paper when paired with paper from $M$. barneyi $(55 \%)$ and C. formosanus (50-60\%), as were a substantial minority when paired with paper from R. flaviceps (40\%). For R. flaviceps, the majority of individuals were always on their own paper, whether paired with $M$. barneyi (75-85\%), C. formosanus (45-60\%), or O. formosanus (50-60\%).

The repeated measures ANOVA found there was no effect of species $\left(F_{3,168}=0.004, p=1.000\right)$, but a significant effect of paper source (own species, other species, or blank; $F_{2,168}=6.420, p=0.002$ ), but there was an interaction effect between them $\left(F_{6,168}=7.621, p<0.001\right)$. There was no effect of time, 
either alone $\left(F_{1,168}=0.021, p=0.886\right)$, or as an interaction with species $\left(F_{3,168}=0.008, p=0.999\right)$, paper source $\left(F_{2,168}=1.552, p=0.215\right)$, or both species and paper source $\left(F_{6,168}=1.624, p=0.143\right)$. Due to the significant interaction between species and paper source, and lack of effect of tie, each species was compared alone at 2 hours.

For M. barneyi, there was no effect of species $\left(F_{2,36}=0.033, p=0.967\right)$ or paper source $\left(F_{2,36}=1.433\right.$, $p=0.252)$, but there was an interaction effect between them $\left(F_{4,36}=9.258, p<0.001\right)$. This was because there was no difference between number of $M$. barneyi on each paper source for $C$. formosanus and $R$. flaviceps, but they avoided O. formosanus paper in preference for their own.

For O. formosanus, there was no effect of species $\left(F_{2,36}=0.031, p=0.969\right)$, but there was a significant effect of paper source $\left(F_{2,36}=8.917, p=0.001\right)$, and there was also an interaction effect between them $\left(F_{4,36}=2.890, p=0.036\right)$. This was because $O$. formosanus generally preferred their own paper and other species paper to blank paper, except for paper from $M$. barneyi, which they avoided.

For $C$. formosanus, there was no effect of species $\left(F_{2,36}=0.000, p=1.000\right)$ or paper source $\left(F_{2,36}=2.528\right.$, $p=0.094)$, and there was no interaction effect between them either $\left(F_{4,36}=1.056, p=0.392\right)$. This was because $C$. formosanus had a relatively variable and thus not significant response, though the general pattern was they preferred blank paper to their own paper and that from M. barneyi, and they preferred other species paper from $O$. formosanus and $R$. flaviceps to either their own or blank paper.

For $R$. flaviceps, there was no effect of species $\left(F_{2,36}=0.002, p=0.998\right)$, but there was a significant effect of paper source $\left(F_{2,36}=7.551, p=0.002\right)$, and there was no interaction effect between them $\left(F_{4,36}=1.331, p=0.277\right)$. This was because $R$. flaviceps preferred their own paper to and other species paper and blank paper, in all circumstances.

\subsection{Field Survey}

There was a clear pattern of more termite activity in the warmer months of the year, with over $40 \%$ of the dead wood containing termites from June through to October, with a peak in September (Figure 7). The cooler months of the year had the lowest termite activity, lower than $10 \%$ of dead wood with termites.

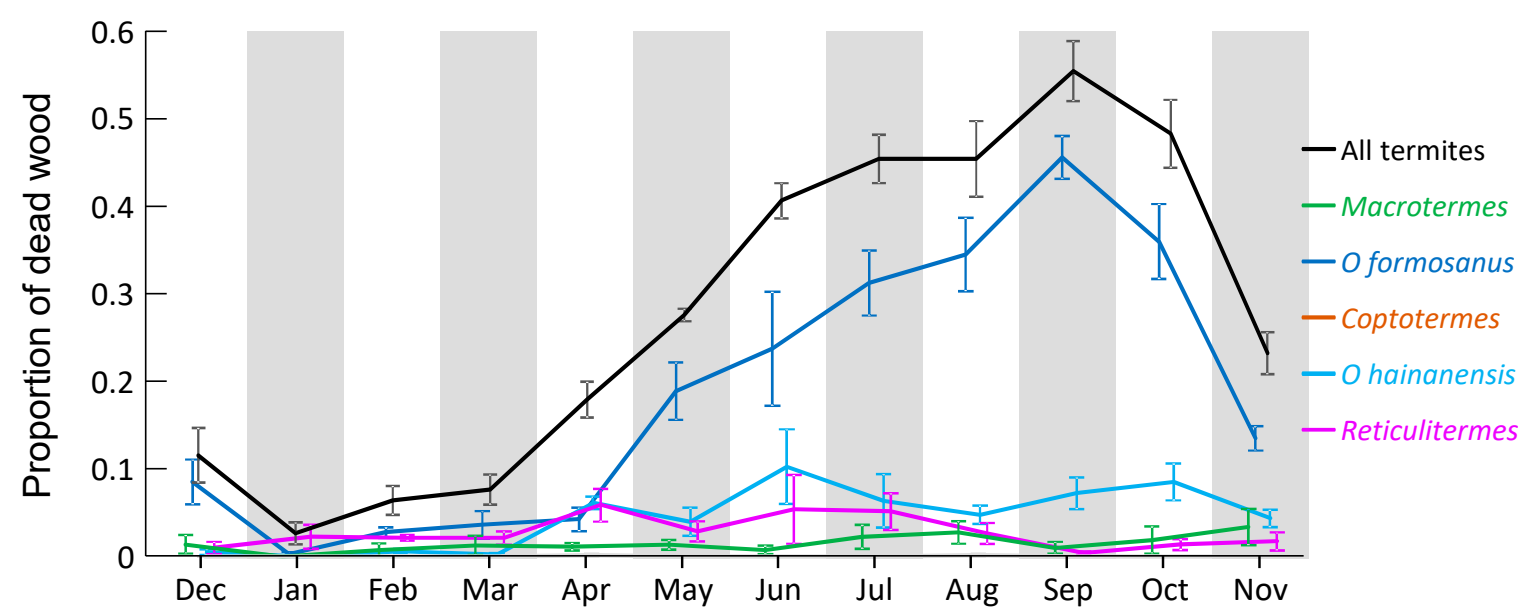

Figure 7. Termite activity over one year in Hangzhou Botanical Gardens, China. Data are average ( \pm standard error) proportion of dead wood on ground containing termites. There were 200 pieces of wood sampled each month.

The majority of the termites found in the dead wood were O. formosanus, then O. hainanenis, $R$. flaviceps, $M$. barneyi, and, rarely, $C$. formosanus. There were very occasional appearances of other species (Pericapritermes jangtsekiangensis and Sinotermes mushao). The number of pieces of wood with termites did vary over the year for $O$. formosanus $\left(1-45 /\right.$ month; $F_{11,36}=23.459, p<0.001$ ), but did not vary over the year for $M$. barneyi $\left(1-5 /\right.$ month; $\left.F_{11,36}=0.727, p=0.706\right)$, C. formosanus $(0-1 /$ month; 
$\left.F_{11,36}=1.987, p=0.060\right)$, O. hainanensis $\left(1-12 /\right.$ month; $\left.F_{11,36}=1.772, p=0.096\right)$, or $R$. flaviceps $(1-6 /$ month; $F_{11,36}=1.241, p=0.297$ (Figure 7).

Considering only the wood in which termites were found, O. formosanus was the most common, with an average proportion across the year of 0.59 of all termites (ranging from 0.23 to 0.83 ). O. hainanensis averaged $0.13(0.00-0.38)$, R. flaviceps averaged 0.19 (0.01-0.67), M. barneyi averaged $0.07(0.00-0.19)$, and C. formosanus averaged $0.001(0.000-0.006)$ (Figure 8).

The ratio of these proportions could change, sometimes dramatically, over the year. For O. formosanus, there were significantly higher proportions in attacked wood pieces in summer $\left(F_{11,35}=6.049 ; p<0.001\right)$, whereas for $O$. hainanensis, there were a significantly higher proportions in early winter, and for $R$. flaviceps, there were a significantly higher proportions in late winter $\left(F_{11,35}=4.513 ; p<0.001\right)$. There were no changes in proportions of attacked wood over the year for either M. barneyi $\left(F_{11,35}=1.297 ; p=0.267\right)$, or $C$. formosanus $\left(F_{11,35}=0.832 ; p=0.610\right)$.

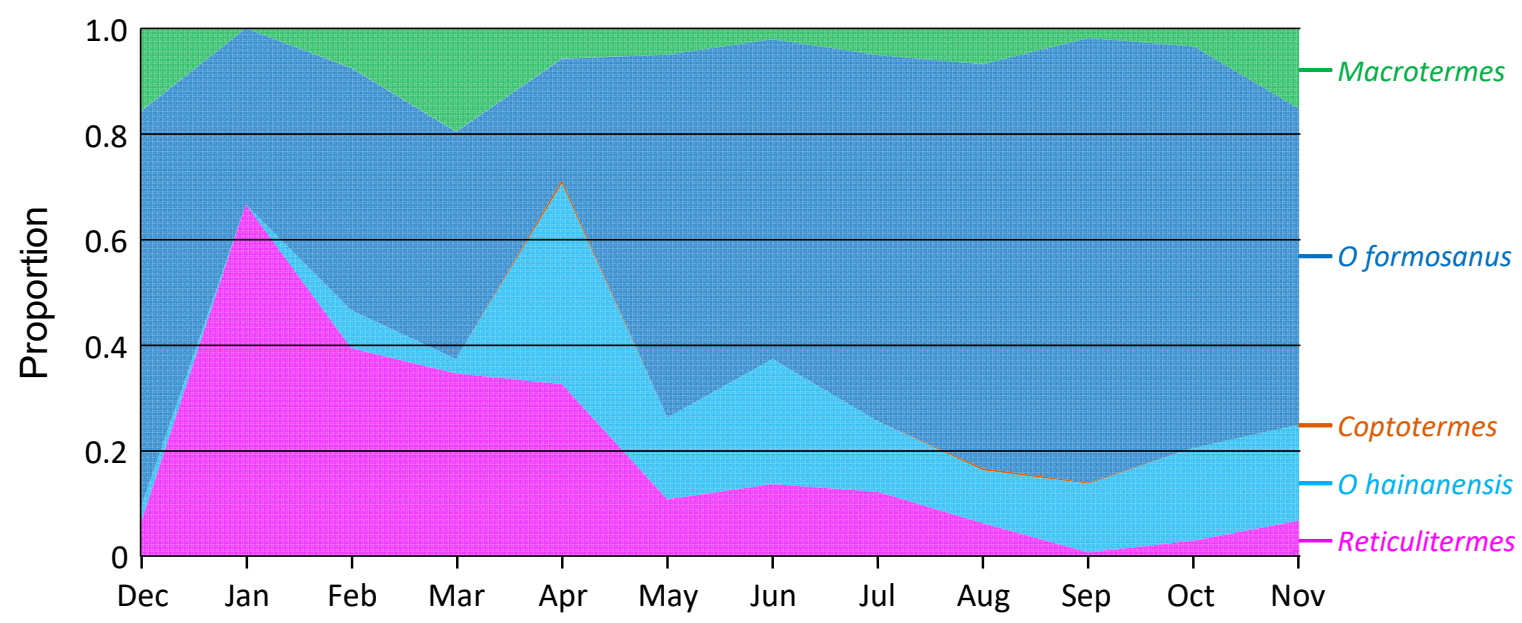

Figure 8. Proportional activity of various termite species in wood containing termites, over one year in Hangzhou Botanical Gardens, China. Data are average ( \pm standard error) proportion of dead wood on ground containing each termite species.

\section{Discussion}

Termites displayed high levels of aggression, typically fighting to the death. Body size was the most important factor affecting survival, regardless of whether equal numbers or biomass of termites were used. The advantage of a large body size difference was overwhelming for equal numbers, and lessened but still important for equal biomass. Termites detect the presence of their own or other termite species from the papers, and their positioning matched the results of the aggression experiments. In general, each species avoided the papers of larger species, and explored the papers of smaller species. Termite foraging activity was generally higher in the summer months, but this varied between species. The largest species, $M$. barneyi, did not change foraging over the year, the most abundant species, $O$. formosanus, increased foraging activity dramatically in summer, and the two smaller species, $O$. hainanensis and $R$. flaviceps, were relatively more abundant in winter.

Taken together, this study suggests that these wood-eating termite species are competing, have evolved a dominance hierarchy, and subordinate species actively avoid dominant species. The dominant species was $M$. barneyi, with $O$. formosanus the first subordinate species, perhaps subdominant, followed by $C$. formosanus, then $O$. hainanensis, and finally $R$. flaviceps. In the Philippines, Macrotermes gilvus was found to attack and kill Coptotermes gestroi, Nasutitermes luzonicus, and Microcerotermes losbanosensis in similar petri dish experiments [35]. The smaller species may have changed their foraging activity to avoid the more dominant larger species [8-11]. Although this is the first study that proposes a dominance hierarchy based on competition for termites, they have been proposed for other social insects, including ants [39-41] and bees [42-45]. 
The hierarchy is based mostly on body size, as with other animals [8], but may be ameliorated by biomass of fighting termites. In any encounter, the biomass of potential fighters would be based in part on the colony size. The population sizes of these species in China are not known; however, the colonies of Macrotermes species in Africa are very populous (several millions), those of Coptotermes species in Australia and Asia somewhat less (half to one million), and those of Reticulitermes species in the USA and Japan much smaller again (tens to hundreds of thousands)—for reviews, see [46,47]. If the population sizes of colonies of the Chinese species match those of their congenerics elsewhere, it would also match the dominance hierarchy observed in the present study.

Termites recognised the habitations (the filter papers) of other species and either avoided those that were more dominant or searched through those that were subordinate. The recognition was likely chemical, either from pheromones secreted by the termites, perhaps deliberately, cuticular hydrocarbons that had rubbed onto paper from movement, or from faeces deposited on the paper-or a combination of all three. All three of these potential signals differ between termites-e.g., pheromones [48-52], gut bacteria $[14,15]$ - but the exact mechanism is unknown. Given that there are termite species that are inquilines of other termite species, such chemical signals may be attractive (to find hosts) as well as repellent (to avoid more dominant competitors) [53]. Note that termites use vibrational signals to find conspecifics [54], competitors [12], and predators such as ants [55], and these signals may be of importance when the termites themselves are active.

The role of competition is not likely to be the only explanation for community structure. Other abiotic and biotic factors are important as well, including weather events, disturbance, microhabitat specialisation, predators, and parasites-e.g., for ants [56-58] and for bees [42]. This is likely to be so for termites as well and may explain some of the patterns found in the current study. The lab data suggested Macrotermes would be dominant, but the field data showed it was less common than either of the two Odonotermes species. This may be because the sampling did not include trees or large fallen branches, and the size of food resources does influence foraging decisions of species of Macrotermes, Coptotermes and Reticulitermes [59-61], and other species [62-64]. The lack of sampling of large food resources was an unintended artefact of human disturbance (management) in the Botanical Gardens.

Human disturbance is well known to change termite communities in all biogeographic provinces [65-69]. The most sensitive species belong to the soil-feeding and soil-interface functional groups. The fungus-growing termites are also sensitive to disturbance, with larger bodied species more likely to disappear (West Africa [66], SE Asia [67,70-72]). Therefore, M. barneyi may have been less abundant in the human managed botanical gardens, than in completely undisturbed native forests. In West Africa, another dominant Macrotermes species, M. bellicosus, was found to be important in structuring the rich termite communities in undisturbed primary forest, but not so in species poor disturbed agricultural land [73].

Species in the Rhinotermitae, such as Coptotermes, become more abundant with disturbance: in logged natural forests [66,67]; in plantations [30,31,74-77]; and particularly in urban areas [78,79]. The main Coptotermes species in China, C. formosanus, was encountered rarely in the survey of the partially disturbed Botantic Gardens field site, but just a few hundred meters away it is a major pest in urban areas, as is common in China [80].

Coptotermes is believed to be rare in forests, because it is rarely encountered in standard transect surveys [65-69]. However, this result may be a sampling artefact, as these surveys do not sample within standing, live tree trunks, which is where Coptotermes evolved to live [12,81]. Coptotermes may have evolved this habit in order to avoid competition with other termites, such as Macrotermes and other fungus-growing species. Although Coptotermes is from the Rhinotermitidae, which is a more basal family than the Macrotermitidae, the genus is younger, having evolved about 25 million years later than the Macrotermitidae $[82,83]$. It is possible that Coptotermes is more common in forests, hiding inside tree trunks, than typically assessed.

Either way, Coptotermes may still increase in abundance from rare(r) in undisturbed forest to common in urban areas. This may be driven due to the loss of the more dominant fungus-growing 
termites from human modification of the landscape: 'competitive' (or 'ecological') release [84]. It may be that human disturbance actually selects for pest species, perhaps with r-selected characteristics [85]. The same may be true for Reticulitermes in cooler locations, such as Japan. It is also possible that Coptotermes has a greater tolerance to the higher temperatures found in urban areas [86].

Therefore, an increase in Coptotermes due to disturbance may be observed due to the absence of the more dominant fungus-growing termites. Fungus-growing termites did not disperse to Australia or New Guinea, whereas Coptotermes did, arriving from Asia around $15 \mathrm{Ma}$ and 5 Ma respectively [82], likely before the Termitidae [83]. Coptotermes diversified and dominate Australian forests, with three species evolving mound building habits [81]. Several Coptotermes species have been introduced by humans to areas without fungus-growing termites and have since become abundant, including in forests in Japan, Madagascar, and the USA $[87,88]$.

\section{Conclusions}

This study found strong aggression competition between five species of wood-eating termites in China. Body size was the most important factor in competition, but this was reduced when biomass was equivalent. The termites detected and responded to used papers (likely chemical signals), with larger species searching through papers from smaller species, and smaller species avoiding papers used by larger species. Finally, activity in the field suggested there was temporal (seasonal) avoidance, with smaller species more active in the winter months. These results suggest there is a dominance hierarchy among the termites in China.

It is likely that dominance hierarchies will vary between termite communities in different biogeographic areas. Africa has the highest diversity of termites, including fungus-growing species [13], so it seems likely that fungus-growing termites will dominant the hierarchy in Africa, as observed in the current study in China. However, Africa has diverse wood-eating termites in the Nasutitermitidae and Amitermitinae $[13,65,66]$, which were not found in the current study, and so their rank in a hierarchy remains unknown. South America is likely to be different again, as there are no fungus-growing termites, but many Nasutitermitidae and Syntermitinae [13,68,69]. Australia is dominated by Coptotermes to a greater degree than any other biogeographic zone, including the only mound-building species [81], suggesting a different pattern of dominance again. There remains much research to uncover competitiveness and dominance hierarchies across all biogeographic zones, and common patterns, if any, can be ascertained.

Author Contributions: Conceptualization, T.A.E.; methodology, T.A.E. and B.D.K.; formal analysis, T.A.E.; resources, T.A.E. and B.D.K.; writing-original draft preparation, T.A.E.; writing-review and editing, T.A.E. and B.D.K.; funding acquisition, T.A.E.

Funding: This research was funded by an Endeavour Executive Award, Australian Government, to T.A.E. for travel to China.

Acknowledgments: We thank Jianchu Mo for hosting T.A.E. in China, and Liu Jing, Yu Wei, and their colleagues of Hangzhou Botanical Garden for their help in field studies.

Conflicts of Interest: The authors declare no conflict of interest.

\section{References}

1. Darwin, C.D. On the Origin of Species by Means of Natural Selection, or the Preservation of Favoured Races in the Struggle for Life. Murray, London, UK, 1859; p. 140. Available online: http://darwin-online.org.uk/ content/frameset?itemID=F373\&viewtype=text\&pageseq=1 (accessed on 13 July 2019).

2. Gause, G.F. The Struggle for Existence. The Williams \& Wilkins Company: Baltimore, MD, USA, 1934. Available online: https://doi.org/10.5962/bhl.title.4489 (accessed on 13 July 2019).

3. Elton, C. Competition and the structure of ecological communities. J. Anim. Ecol. 1946, 15, 54-68. [CrossRef]

4. Park, T.; Gregg, E.V.; Lutherman, C.Z. Studies in population pysiology. X. Interspecific competition in populations of granary beetles. Physiol. Zool. 1941, 14, 395-430. [CrossRef] 
5. Crombie, A.C. On competition between different species of graminivorous insects. Proc. R. Soc. B 1945, 132, 362-395. [CrossRef]

6. Crombie, A.C. Further experiments on insect competition. Proc. R. Soc. B 1946, 133, 76-109. [CrossRef]

7. Park, T. Interspecies competition in populations of Trilobium confusum Duval and Trilobium castaneum Herbst. Ecol. Monogr. 1948, 18, 265-307. [CrossRef]

8. Schoener, T.W. Field experiments on interspecific competition. Am. Nat. 1983, 122, 240-285. [CrossRef]

9. Carothers, J.H.; Jaksić, F.M. Time as a niche difference: The role of interference competition. Oikos 1984, 42, 403-406. [CrossRef]

10. Davidson, D.W. An experimental study of diffuse competition in harvester ants. Am. Nat. 1985, 125, 500-506. [CrossRef]

11. Kronfeld-Schor, N.; Dayan, T. Partitioning of time as an ecological resource. Ann. Rev. Ecol. Evol. Syst. 2003, 34, 153-181. [CrossRef]

12. Evans, T.A.; Inta, R.; Lai, J.C.S.; Prueger, S.; Foo, N.W.; Fu, E.W.; Lenz, M. Termites eavesdrop to avoid competitors. Proc. R. Soc. B 2009, 276, 4035-4041. [CrossRef]

13. Eggleton, P.; Tayasu, I. Feeding groups, lifetypes and the global ecology of termites. Ecol. Res. 2001, 16, 941-960. [CrossRef]

14. Ohkuma, M.; Brune, A. Diversity, structure, and evolution of the termite gut microbial community. In Biology of Termites: A Modern Synthesis; Bignell, D., Roisin, Y., Lo, N., Eds.; Springer: Dordrecht, Netherlands, 2011; pp. 413-438, ISBN 978-90-481-3976-7.

15. Brune, A.; Dietrich, C. The gut microbiota of termites: Digesting the diversity in the light of ecology and evolution. Ann. Rev. Microbiol. 2015, 69, 145-166. [CrossRef] [PubMed]

16. Bultman, J.D.; Southwell, C.R. Natural resistance of tropical American woods to terrestrial wood-destroying organisms. Biotropica 1976, 8, 71-95. [CrossRef]

17. Wood, T.G.; Sands, W.A. The role of termites in ecosystems. In Production Ecology of Ants and Termites; Brian, M.V., Ed.; Cambridge University Press: Cambridge, UK, 1978; pp. 245-292, ISBN 0521215196.

18. Scheffer, T.C.; Morrell, J.J. Natural Durability of Wood: A Worldwide Checklist of Species. Oregon State University, Forest Research Laboratory, Technical Report 22. 1998. Available online: https://ir.library. oregonstate.edu/concern/technical_reports/dz010r37p (accessed on 13 July 2019).

19. Nel, J.J.C. Aggressive behaviour of the harvester termites Hodotermes mossambicus (Hagen) and Trinervitermes trinervoides (Sjöstedt). Insectes Soc. 1968, 15, 145-156. [CrossRef]

20. Thorne, B.L.; Haverty, M.I. Review of intracolony, intraspecific and interspecific agonism in termites. Sociobiology 1991, 19, 115-145.

21. Shelton, T.G.; Grace, J.K. Review of agonistic behaviors in the Isoptera. Sociobiology 1996, 28, $155-176$.

22. Adams, E.S. Nest-mate recognition based on heritable odors in the termite Microcerotermes arboreus. Proc. Natl. Acad. Sci. USA 1991, 88, 2031-2034. [CrossRef]

23. Haverty, M.I.; Thorne, B.L. Agonistic behavior correlated with hydrocarbon phenotypes in dampwood termites, Zootermopsis (Isoptera: Termopsidae). J. Insect Behav. 1989, 2, 523-543. [CrossRef]

24. Bagneres, A.-G.; Killian, A.; Clement, J.-L.; Lange, C. Interspecific recognition among termites of the genus Reticulitermes: Evidence for a role for the cuticular hydrocarbons. J. Chem. Ecol. 1991, 17, 2397-2420. [CrossRef]

25. Bagnères, A.-G.; Hanus, R. Communication and social regulation in termites. In Social Recognition in Invertebrates; Aquiloni, L., Tricarico, E., Eds.; Springer: Cham, Switzerland, 2015; pp. 193-248, ISBN 978-3-319-17598-0.

26. Gontijo, T.A.; Domingos, D.J. Guild distribution of some termites from cerrado vegetation in south-east Brazil. J. Trop. Ecol. 1991, 7, 523-529. [CrossRef]

27. Korb, J.; Linsenmair, K.E. The causes of spatial patterning of mounds of a fungus-cultivating termite: Results from nearest-neighbour analysis and ecological studies. Oecologia 2001, 127, 324-333. [CrossRef] [PubMed]

28. Davies, A.B.; Levick, S.R.; Asner, G.P.; Robertson, M.P.; van Rensburg, B.J.; Parr, C.L. Spatial variability and abiotic determinants of termite mounds throughout a savanna catchment. Ecography 2014, 37, 852-862. [CrossRef]

29. Huang, F.S.; Zhu, S.M.; Ping, Z.M.; He, X.S.; Li, G.X.; Gao, D.R. Isoptera. In Fauna Sinica, Insecta; Science Press: Beijing, China, 2000; Volume 17. (In Chinese) 
30. Cowie, R.H.; Logan, J.W.M.; Wood, T.G. Termite (Isoptera) damage and control in tropical forestry with special reference to Africa and Indo-Malaysia: A review. Bull. Ent. Res. 1989, 79, 173-184. [CrossRef]

31. Constantino, R. The pest termites of South America: Taxonomy, distribution and status. J. Appl. Ent. 2002, 126, 355-365. [CrossRef]

32. Rouland-Lefèvre, C. Termites as pests of agriculture. In Biology of Termites: A Modern Synthesis; Bignell, D., Roisin, Y., Lo, N., Eds.; Springer: Dordrecht, The Netherlands, 2011; pp. 499-517, ISBN 978-90-481-3976-7.

33. Polizzi, J.M.; Forschler, B.T. Factors that affect aggression among the worker caste of Reticulitermes spp. subterranean termites (Isoptera: Rhinotermitidae). J. Insect Behav. 1999, 12, 133-146. [CrossRef]

34. Wong, N.; Lee, C.-Y. Intra- and interspecific agonistic behavior of the subterranean termite Microcerotermes crassus (Isoptera: Termitidae). J. Econ. Entomol. 2010, 103, 1754-1760. [CrossRef]

35. Rojo, M.J.A.; Acda, M.N. Interspecific agonistic behavior of Macrotermes gilvus (Isoptera: Termitidae): Implication on termite baiting in the Philippines. J. Insect Behav 2016, 273-282. [CrossRef]

36. Simkovic, V.; Thompson, G.J.; McNeil, J.N. Testing for aggression and nestmate recognition in the Eastern subterranean termite (Reticulitermes flavipes). Insectes Sociaux 2018, 65, 281-288. [CrossRef]

37. Thorne, B.L. Termite-termite interactions: Workers as an agonistic caste. Psyche 1982, 89, 133-150. [CrossRef]

38. Cornelius, M.L.; Osbrink, W.L.A. Bioassay design and length of time in the laboratory affect intercolonial interactions of the Formosan subterranean termite (Isoptera, Rhinotermitidae). Insectes Soc. 2009, 56, $203-211$. [CrossRef]

39. Savolainen, R.; Vepsäläinen, K. A competition hierarchy among boreal ants: Impact on resource partitioning and community structure. Oikos 1988, 51, 135-155. [CrossRef]

40. Andersen, A.N.; Patel, A.D. Meat ants as dominant members of Australian ant communities: An experimental test of their influence on the foraging success and forager abundance of other species. Oecologia 1994, 98, 15-24. [CrossRef] [PubMed]

41. Cerdá, X.; Retana, J.; Manzaneda, A. The role of competition by dominants and temperature in the foraging of subordinate species in Mediterranean ant communities. Oecologia 1998, 117, 404-412. [CrossRef] [PubMed]

42. Wcislo, W.T.; Arneson, L.; Roesch, K.; Gonzalez, V.; Smith, A.; Fernández, H. The evolution of nocturnal behaviour in sweat bees, Megalopta genalis and M. ecuadoria (Hymenoptera: Halictidae): An escape from competitors and enemies? Biol. J. Linn. Soc. 2004, 83, 377-387. [CrossRef]

43. Wcislo, W.T.; Tierney, S.M. Behavioural environments and niche construction: The evolution of dim-light foraging in bees. Biol. Rev. 2009, 84, 19-37. [CrossRef]

44. Shavit, O.; Dafni, A.; Ne'eman, G. Competition between honeybees (Apis mellifera) and native solitary bees in the Mediterranean region of Israel-Implications for conservation. Israel J. Plant Sci. 2009, 57, 171-183. [CrossRef]

45. Smith, A.R.; Kitchen, S.M.; Toney, R.M.; Ziegler, C. Is nocturnal foraging in a tropical bee an escape from interference competition? J. Insect Sci. 2017, 17, 62. [CrossRef] [PubMed]

46. Evans, T.A.; Lenz, M.; Gleeson, P.V. Testing assumptions of mark-recapture protocols for estimating population size using Australian mound-building, subterranean termites. Ecol. Entomol. 1998, 23, 139-159. [CrossRef]

47. Evans, T.A.; Lenz, M.; Gleeson, P.V. Estimating population size and forager movement in a tropical subterranean termite (Isoptera: Rhinotermitidae). Environ. Entomol. 1999, 28, 823-830. [CrossRef]

48. Noirot, C. Glands and secretion. In Biology of Termites, vol. 1; Krishna, K., Weesner, F.M., Eds.; Academic Press: New York, NY, USA, 1969; pp. 89-123, ISBN 978-0-12-4263017/978-0-12-395529-6.

49. Prestwich, G.D. Chemical systematics of termite exocrine secretions. Ann. Rev. Ecol. Syst. 1983, 14, $287-311$. [CrossRef]

50. Costa-Leonardo, A.M.; Haifig, I. Pheromones and exocrine glands in Isoptera. Vitamins Hormones 2010, 83, 521-549. [CrossRef]

51. Bordereau, C.; Pasteels, J.M. Pheromones and chemical ecology of dispersal and foraging in termites. In Biology of Termites: A Modern Synthesis; Bignell, D., Roisin, Y., Lo, N., Eds.; Springer: Dordrecht, The Netherlands, 2011; pp. 279-320, ISBN 978-90-481-3976-7.

52. Palma-Onetto, V.; Pflegerová, J.; Plarre, R.; Synek, J.; Cvačka, J.; Sillam-Dussès, D.; Šobotník, J. The labral gland in termites: Evolution and function. Biol. J. Linn. Soc. 2019, 126, 587-597. [CrossRef] 
53. Jirošová, A.; Sillam-Dussès, D.; Kyjaková, P.; Kalinová, B.; Dolejšová, K.; Jančařík, A.; Majer, P.; Cristaldo, P.F.; Hanus, R. Smells like home: Chemically mediated co-habitation of two termite species in a single nest. J. Chem. Ecol. 2016, 42, 1070-1081. [CrossRef] [PubMed]

54. Evans, T.A.; Inta, R.; Lai, J.C.S.; Lenz, M. Foraging vibration signals attract foragers and identify food size in the drywood termite, Cryptotermes secundus. Insectes Soc. 2007, 374-382. [CrossRef]

55. Oberst, S.; Bann, G.; Lai, J.C.S.; Evans, T.A. Cryptic termites avoid predatory ants by eavesdropping on vibrational cues from their footsteps. Ecol. Lett. 2017, 20, 212-221. [CrossRef] [PubMed]

56. Ribas, C.R.; Schoereder, J.H. Are all ant mosaics caused by competition? Oecologia 2002, 131, 606-611. [CrossRef] [PubMed]

57. Cerdá, X.; Arnan, X.; Retana, J. Is competition a significant hallmark of ant (Hymenoptera: Formicidae) ecology? Myrmecol. News 2013, 131-147.

58. Stuble, K.L.; Jurić, I.; Cerdá, X.; Sanders, N.J. Dominance hierarchies are a dominant paradigm in ant ecology (Hymenoptera: Formicidae), but should they be? And what is a dominance hierarchy anyways? Myrmecol. News 2017, 24, 71-81.

59. Lenz, M.; Kard, B.; Mauldin, J.K.; Evans, T.A.; Etheridge, J.L.; Abbey, H.M. Size of food resource determines brood placement in Reticulitermes flavipes. Sociobiology 2001, 37, 361-362.

60. Evans, T.A.; Gleeson, P.V. The effect of bait size, composition, presentation and inspection frequency on bait consumption in termites (Isoptera: Rhinotermitidae). Bull. Ent. Res. 2006, 96, 85-90. [CrossRef]

61. Iqbal, N.; Wijedasa, L.S.; Evans, T.A. Bait station preferences in two Macrotermes species. J. Pest Sci. 2017, 90, 217-225. [CrossRef]

62. Korb, J.; Schmidinger, S. Help or disperse? Cooperation in termites influenced by food conditions. Behav. Ecol. Sociobiol. 2004, 56, 89-95. [CrossRef]

63. Evans, T.A.; Inta, R.; Lai, J.C.S. Foraging choice and replacement reproductives facilitate invasiveness in drywood termites. Biol. Invasions 2011, 13, 1579-1587. [CrossRef]

64. Souza, T.S.; Gazal, V.S.; Fernandes, V.J.; Oliveira, A.C.C.; Aguiar-Menezes, E.L. Influence of food resource size on the foraging behavior of Nasutitermes corniger (Motschulsky). Sociobiology 2018, 65, 291-298. [CrossRef]

65. Eggleton, P.; Bignell, D.E.; Sands, W.A.; Waite, B.; Wood, T.G.; Lawton, J.H. The species richness of termites (Isoptera) under differing levels of forest disturbance in the Mbalmayo Forest Reserve, southern Cameroon. J. Trop. Ecol. 1995, 11, 85-98. [CrossRef]

66. Eggleton, P.; Bignell, D.E.; Hauser, S.; Dibog, L.; Norgrove, L.; Madong, B. Termite diversity across an anthropogenic disturbance gradient in the humid forest zone of West Africa. Agric. Ecosyst. Environ. 2002, 90, 189-202. [CrossRef]

67. Jones, D.T.; Susilo, F.X.; Bignell, D.E.; Hardiwinoto, S.; Gillison, A.N.; Eggleton, P. Termite assemblage collapse along a land-use intensification gradient in lowland central Sumatra, Indonesia. J. Appl. Ecol. 2003, 40, 380-391. [CrossRef]

68. Bandeira, A.G.; Vasconcellos, A.; Silva, M.p.; Constantino, R. Effects of habitat disturbance on the termite fauna in a highland humid forest in the caatinga domain, Brazil. Sociobiology 2003, 42, 1-11.

69. Carrijo, T.F.; Brandão, D.; de Oliveira, D.E.; Costa, D.A.; Santos, T. Effects of pasture implantation on the termite (Isoptera) fauna in the Central Brazilian Savanna (Cerrado). J. Insect Conserv. 2009, 13, 575-581. [CrossRef]

70. Gathorne-Hardy, F.J.; Syaukani; Eggleton, P. The effects of altitude and rainfall on the composition of the termites (Isoptera) of the Leuser Ecosystem (Sumatra, Indonesia). J. Trop. Ecol. 2001, 17, 379-393. [CrossRef]

71. Gathorne-Hardy, F.J.; Syaukani; Inward, D.J.G. Recovery of termite (Isoptera) assemblage structure from shifting cultivation in Barito Ulu, Kalimantan, Indonesia. J. Trop. Ecol. 2006, 22, 605-608. [CrossRef]

72. Bourguignon, T.; Dahlsjö, C.A.L.; Jacquemin, J.; Gang, L.; Wijedasa, L.S.; Evans, T.A. Ant and termite communities in isolated and continuous forest fragments in Singapore. Insectes Soc. 2017, 64, 505-514. [CrossRef]

73. Hausberger, B.; Korb, J. The impact of anthropogenic disturbance on assembly patterns of termite communities. Biotropica 2016, 48, 356-364. [CrossRef]

74. Kalshoven, L.G.E. Observations on Coptotermes havilandi Holmgr. (javanicus Kemn.) (Isoptera). Beaufortia 1962, 101, 121-137.

75. Harris, W.V. On the genus Coptotermes in Africa (Isoptera: Rhinotermitidae). Proc. R. Entomol. Soc. Lond. B 1966, 35, 161-171. [CrossRef] 
76. Jasmi, A.H.; Ahmad, A.H. Termite incidence on an araucaria plantation forest in Teluk Bahang, Penang. Insects 2011, 2, 469-474. [CrossRef] [PubMed]

77. Harris, W.V. The role of termites in tropical forestry. Insectes Soc. 1966, 13, 255-266. [CrossRef]

78. Acda, M.N. Economically important termites (Isoptera) of the Philippines their control. Sociobiology 2004, 43, 159-169.

79. Lee, C.-Y.; Vongkaluang, C.; Lenz, M. Challenges to subterranean termite management of multi-genera faunas in Southeast Asia and Australia. Sociobiology 2007, 50, 213-221.

80. Zhong, J.; Liu, L. Experience with Coptotermes formosanus in China (Isoptera: Rhinotermitidae). Sociobiology 2003, 41, 17-26.

81. Lee, T.R.C.; Evans, T.A.; Cameron, S.L.; Hochuli, D.F.; Ho, S.Y.W.; Lo, N. Ecological diversification of the Australian Coptotermes termites and the evolution of mound building. J. Biogeogr. 2017, 44, 1405-1417. [CrossRef]

82. Bourguignon, T.; Lo, N.; Šobotník, J.; Sillam-Dussès, D.; Roisin, Y.; Evans, T.A. Oceanic dispersal, vicariance and human introduction shaped the modern distribution of the termites Reticulitermes, Heterotermes and Coptotermes. Proc. R. Soc. B 2016, 283, 20160179. [CrossRef] [PubMed]

83. Bourguignon, T.; Lo, N.; Šobotník, J.; Ho, S.Y.W.; Iqbal, N.; Coissac, E.; Lee, M.; Jendryka, M.M.; Sillam-Dussès, D.; Kř́žková, B.; et al. Mitochondrial phylogenomics resolves the global spread of higher termites, ecosystem engineers of the tropics. Mol. Biol. Evol. 2017, 34, 589-597. [CrossRef]

84. Case, T.J.; Gilpin, M.E. Interference Competition and Niche Theory. Proc. Natl. Acad. Sci. USA 1974, 71, 3073-3077. [CrossRef]

85. Schyra, J.; Korb, J. Termite communities along a disturbance gradient in a west African savanna. Insects 2019, 10, 17. [CrossRef]

86. Woon, J.S.; Boyle, M.J.W.; Ewers, R.M.; Chung, A.; Eggleton, P. Termite environmental tolerances are more linked to desiccation than temperature in modified tropical forests. Insectes Sociaux 2019, 66, 57-64. [CrossRef]

87. Evans, T.A.; Forschler, B.T.; Grace, J.K. Biology of invasive termites: A worldwide review. Ann. Rev. Entomol. 2013, 58, 455-474. [CrossRef]

88. Evans, T.A.; Forschler, B.T.; Trettin, C.C. Not just urban: The Formosan subterranean termite, Coptotermes formosanus, is invading forests in the Southeastern USA. Biol. Invasions 2019, 21, 1283-1294. [CrossRef] 